\title{
Improve Quality Remanufacturing Welding and Machining Process in Indonesia Using Six Sigma Methods
}

\author{
Saryanto Saryanto, Humiras Hardi Purba*, Aris Trimarjoko \\ Master of Industrial Engineering Program, Mercu Buana University, Jakarta 11650, Indonesia
}

Corresponding Author Email: humiras.hardi@mercubuana.ac.id

https://doi.org/10.18280/jesa.530308

Received: 20 April 2020

Accepted: 16 May 2020

\section{Keywords:}

quality improvement, remanufacturing, six sigma, product failure, availability, failure mode, DMAIC

\begin{abstract}
Welding and machining processes for Lift Arm Repair in Remanufacturing heavy-duty companies in Indonesia has produced parts according to customer specifications, but the company still has the intention to reduce the level of damage and Cost of Poor Quality. The purpose of this study is to demonstrate the application of the Six Sigma method with the DMAIC cycle (Define, Measure, Analyze, Improve and Control). Other tools to analyze this problem are the Pareto Diagram and the Cause and Effect Diagram. The level of product defects in the Lift Arm Remanufacturing process is relatively high, namely $73.5 \%$ over the past 5 months with the categories of Miss Alignment (68.5\%), Porosity (18.9\%), Crack (4.5\%), Oversize (2.7\%) Scratches (2.7\%) and Others (2.7\%). with a value of 834586.47 DPMO and is at 1.91 sigma with a COPQ of Rp.650,800,000.00. The Six Sigma approach with the DMAIC method is a systematic method that focuses on improving processes. From the DMAIC method, it can be known the factors that cause defect miss alignment and porosity through the cause diagram. After Six Sigma implementation, the level of defective products decreased from 73.5 to $7.03 \%$ with an increase in quality from 1.91 to 2.43 Sigma. Finally, we can reduce COPQ from IDR $650,800,000$ to IDR $135,000,000$ or $66.47 \%$ from the previous condition.
\end{abstract}

\section{INTRODUCTION}

The Remanufacturing industry began in 2015 when the United States Environment Protection Agency (EPA) implemented a Comprehensive Procurement Guidelines (CPG) program to enact waste reduction and resource conservation through the Reuse of used materials and ensuring recycling programs for certain materials can be made into materials to create new products. Roman world Magazine, March/April edition, 2018 states the remanufacturing industry is spreading in various countries with a total forecast of $\$ 160$ billion/year with spread: the USA \$ 100 billion, Europe \$32, Asia \$ 27 billion and Brazil \$ 1.4 billion. The Asian region (including Indonesia) ranks third in the distribution of the remanufacturing industry.

The high remanufacturing forecast reaching 160 billion dollars/year in the remanufacturing industry is a promising business opportunity. However, the remanufacturing industry has a higher risk of product failure compared to original equipment products. In Indonesia, the remanufacturing industry, which is engaged in the Heavy-duty equipment industry, supports the repair of mining equipment and vehicles both in open pit and underground in running its production, experiencing a product failure rate of 834586.47 DPMO if the capability of the process is measured at the level of 1.91 sigma and the Cost of Poor Quality must be borne by IDR. $650,800,000.00$ for January $\sim$ May 2019. Valles et al. [1] state that Six Sigma is a strategy of continuous organizational improvement to find and eliminate the causes of errors, damage, and de-lays in business organization processes. Gijo et al. [2] with the application of the Six Sigma method resulted in a reduction intolerance related to problems and increased yield values from $85 \%$ to more than $99 \%$. Get a total savings of US $\$ 70,000$ per year. Hassan [3] shows that, for the calculation of the yield value of $95.75 \%$, from this result, the sigma level was calculated and found an initial sigma value of 3.22 and a DPMO of 42,500 . Using a target of a $2 \%$ defect rate, the target sigma value is calculated to be 3.55 and the DPMO value is 20.000 . The results achieved $98.24 \%$, according to the sigma level of 3.6 and the DPMO value of 17.600. Referring to various studies on problem-solving with the help of Six Sigma methods showing positive results that are marked by decreasing product failure rates and increasing sigma levels, then in this study, Six Sigma methods are expected to be used in the failure of remanufacturing lift arm products in the Heavy-duty industry in Indonesia to be reduced so that the process capability is getting better, COPQ can be suppressed and will certainly increase company profits.

This research was conducted to examine the level of disability in the Machine Rebuild section with the Machining and Welding process in the company. The section is the final section of the process in the production process, where the level of disability is still high based on the 2018 Machining and Welding quality reports. Based on internal data of the 2018 Machining and Welding product defects, $1.99 \%$ with types of defective products as follows: Lift Arm (73.5\%), Bucket (7.9\%), Front Frame (3.3\%), Rear Frame (3.3\%), Tilt Lever (3.3\%), Tilt Link (2.6\%), Cabin $(2.0 \%)$ and others $(4.0 \%)$. Based on the 2018 defect product data, this study is motivated to re-duce the Lift Arm product failure of the Machining and Welding process which has the highest accumulation of defective products by $73.5 \%$, with the hope 
that Lift Arm quality can be improved to meet customer satisfaction and provide a more optimal company advantage.

\subsection{Quality improvement}

Speaking of quality, of course, there is no definite understanding of quality and quality has a broad scope and has a different understanding [4]. Quality can be seen as a point of fulfillment to customer demand and satisfaction [5]. Quality in terms of producers is the fulfillment of quality standards that have been owned [6]. So that quality can be interpreted by how much the ability of producers to meet the standards owned to satisfy the desires and expectations of customers [7]. Referring to the definition of quality, the improvement of product quality to increase customer satisfaction is an important attribute in a business organization [8]. Customer satisfaction can be formed if customers get what is expected from a product or service it uses [9]. In this fact the industrial world is expected to identify the attributes that will affect customer satisfaction then design and create it into superior products and services according to the wishes and expectations of customers. Quality improvement is a company policy that must be done to maintain customer satisfaction and resistance in question. Quality improvement is a series of group and individual activities that focus on reducing the variety of processes and products with systematic and measurable methods aimed at reducing any waste [10]. The process of improving quality is identifying quality indicators, monitor these indicators and measuring the results of these quality indicators which of course lead to the outcome, and always focus to improve the process, so the quality of the results/products will improve. Because it is believed that quality improvement greatly influences the company's profitability and competitiveness [11-13].

\subsection{Remanufacturing industry}

In 2005 the remanufacturing industry began when the United States Environmental Protection Agency (EPA) implemented a comprehensive procurement Guidance program (CPG) to enact waste reduction and resource conservation guidelines through the Reuse of waste materials and ensuring recycling programs for certain materials can be made into materials to create new products. In 2004, the EPA established several remanufactured vehicle parts. Remanufacturing is to use a portion of its original form and replace or rebuild damaged parts. The testing process follows the same specification process as the new product manufacturing process (https://www.epa.gov/). Remanufacturing is the process of bringing used products to a "new-like" functional state by rebuilding and replacing existing parts [14].

The remanufacturing industry is an industry that uses a portion of its original form/original equipment to rebuild damaged parts and replace it with new equipment through the testing process following the same specifications as the new product manufacturing process. The quality of Remanufacturing products has the same standard as the manufacturing of new products $[15,16]$. Three main factors are the reasons why industrial remanufacturing is the choice [17], namely: (1) ecological factors, namely reducing waste caused by the product life cycle that has run out, (2) the legal factor with the increasing number of wastes as point 1 certain countries have enacted legislation regarding recycle products,
(3) economic factors, the increasing price of new products to guarantee industrial remanufacturing provides attractive choices with quality standards for new products. Referring to some of these studies it can be understood that the concept of remanufacturing is one of the effective choices in the industrial world because, in addition to providing financial benefits for companies, it can also provide non-financial benefits in the form of customer satisfaction and also support legal legitimacy or government policy.

\section{METHODOLOGY}

Quality is a dynamic condition related to products, services, people, processes and the environment that meets or exceeds expectations, speaking of quality there is certainly no definite understanding of quality and quality has a broad scope and has a different understanding $[4,18]$. Quality can be seen as a point of fulfillment to customer demand and satisfaction [5], Quality in terms of producers is the fulfillment of quality standards that have been owned [6]. So that quality can be interpreted by how much the ability of producers to meet the standards owned to satisfy the desires and expectations of customers [7]. Referring to the understanding of quality that the improvement of product quality to increase customer satisfaction becomes a very im-portant attribute in business organizations (industry).

Some various strategies or methods can be used to improve product quality including the Six Sigma method. Six Sigma is one of the methods of improvement and quality control that has been implemented by many companies or organizations. The Six Sigma concept is to put forward the principle of $3 \sim 4$ defective products per one million products proven to be able to increase the competitiveness of companies or organizations [19-21]. Six Sigma is an effective and flexi-ble system for achieving, maintaining and maximizing business success. Six Sigma is uniquely controlled by a strong understanding of customer needs, the discipline of using data, facts, and analysis statistically, as well as paying careful attention to managing, improving and reviewing business processes to achieve the 6 sigma target [22].

Researchers The research methodology is a systematic description of the steps taken by the author from the beginning to the end of the study so that the implementation of the research becomes clear and focused following the research objectives. Through the following principal steps: (1) Describe the issue that is happening (2) Measure baseline performance or sigma level as an initial standard Remanufacturing the Lift Arm process. (3) Analyzing the cause of product failure fac-tors in the Lift Arm Remanufacturing process. (4) Determine the improvement efforts that can be done to improve the quality of the Re-manufacturing Lift Arm process, (5) Evaluate and control the results of repairs. The 5 stages are following the rules of problem-solving using the Six Sigma method namely the DMAIC phases (Define, Measure, Analyze, Improvement and Control). The research methodology used in this study is shown in Figure 1

Six Sigma as a management system is applied to ensure that efforts and critical opportunities for improvement are well developed through metric methodology and an applied level is in line with its business strategy. Six Sigma enables an organization to improve quality process by identifying and eliminating the causes of defects and error terms through minimizing variability in manufacturing and business processes [23]. The stages for improve process ability (process 
capability) regarding Six Sigma method are specifically allowing the standard steps such as define, measure, analyze, improve, and control for interlinked statistical tests. For a particular project within organization of applied of Six Sigma the stage is typically consists of a step-by-step requires for obtain measurable target values i.e. reduces cycle time, decreases air pollution, reduces costs, improves customer satisfaction, and increases profits [23]. It is inevitable, in order to gain benefits, as a results of Six Sigma's application in an organization or company, would require relatively high of initial investment, but might be offer benefits in long terms including cost savings, generated profits, improved consistency of quality processes, better employee performance, and better service quality and products. Those elements particularly would lead an organization or company to provide a higher customer satisfaction as well as to gain the ultimate goal of organization [23]. By applying DMAIC using a statistical approach, the root causes of the problem can be found and can improve the production process. The results of the six sigma improvement show the process capability increased from 2.2 to 3.1 sigma, saving \$18,394.2 per month [24]. Six sigma is a systematic, flexible, measurable and effective method in solving various problems in the industrial world [25]. Seeing the results of the studies mentioned above, the Six Sigma method is used in improving the quality of Remanufacturing Lift Arm in the Heavy-duty equipment industry in Indonesia to be better to meet customer satisfaction and provide better company benefits.

\section{RESULTS AND DISCUSSIONS}

The research methodology is a systematic description of the steps taken by the author from the beginning to the end of the study so that the implementation of the research becomes clear and focused following the research objectives. Through the following principal steps: (1) Describe the issue that is happening (2) Measure baseline performance or sigma level as an initial standard Re-manufacturing the Lift Arm process. (3) Analysing the cause of product failure factors in the Lift Arm Remanufacturing process. (4) Determine the improvement efforts that can be done to improve the quality of the Remanufacturing Lift Arm process, (5) Evaluate and control the results of repairs. The 5 stages are following the rules of problem-solving using the Six Sigma method namely the DMAIC phases (Define, Measure, Analyze, Improvement and Control)

\subsection{Define phase}

At the stage of defining activities carried out to identify problems that occur based on consumer needs and determination of goals (reduction of product failure). The initial step of the define stage is to identify the sequence of activities that occur in the welding and machining process that aims to find out at which stage the problem is. As for the sequence of activities intended in the SIPOC Diagram as in Figure 2.

The Welding and Machining process is critical in this research. The next step is to find out the Critical to Quality in the Lift Arm welding dam machining process is carried out the production data collection and Welding and Machining Lift Arm product failure in January May 2019 with the percentage and types of product failure as in Pareto diagram Figure 3.

Refer to the Pareto diagram as in Figure 3. Can be interpreted that 6 types of defective products occur in the welding process and Machining Lift Arm, namely: Miss Alignment (68.5\%), Porosity (18.9\%), Crack (4.5\%), Oversize $(2.7 \%)$ Scratches $(2.7 \%)$ and Others $(2.7 \%)$. Based on the concept of Pareto product failure that has an accumulation of $80 \%$ into the improvement priori-ty in problem-solving, then CTQ in this study there are 2 types are Miss Alignment and Porosity product failure.

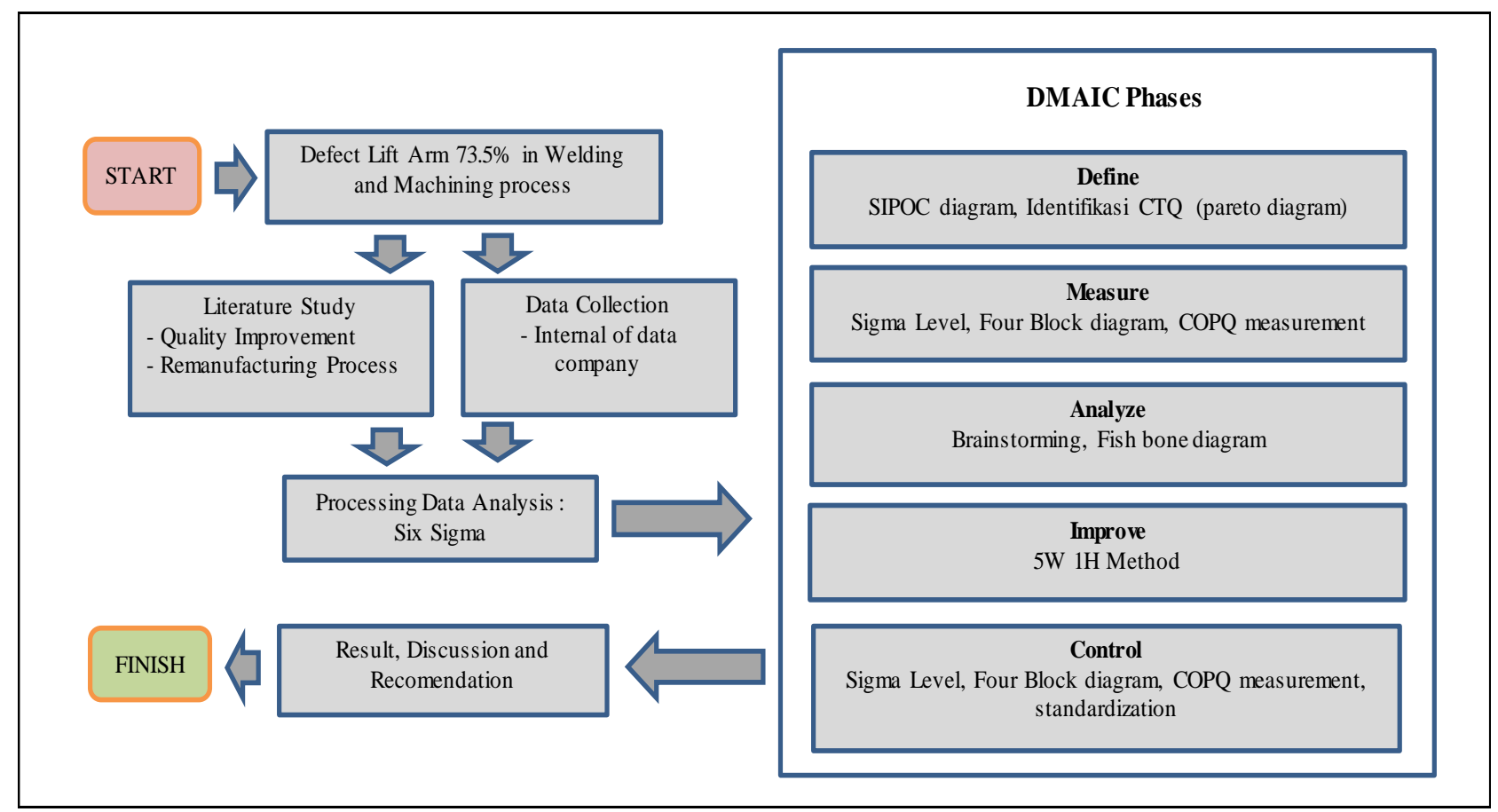

Figure 1. Research methodology of problem solving of lift arm in welding and machining process 


\begin{tabular}{|l|l|l|l|l|}
\hline \multicolumn{1}{|c|}{ Supplier } & \multicolumn{1}{c|}{$\boldsymbol{C}$ Input } \\
\hline Attachment (has been & Damage part & Welding and & Part finish process & Assembly area \\
dismantled and washed) & Consumable welding: & Machining process & Remanufacturing & \\
Scope of work & Wire, argon, contact tip & & with OK tag & \\
Schedule & Consumable Machining: & & & \\
Material (has been cut & insert, cool and, tap matrix, & & & \\
according to SOW) & holder tools & & & \\
\hline
\end{tabular}

Figure 2. SIPOC diagram of remanufacturing lift arm

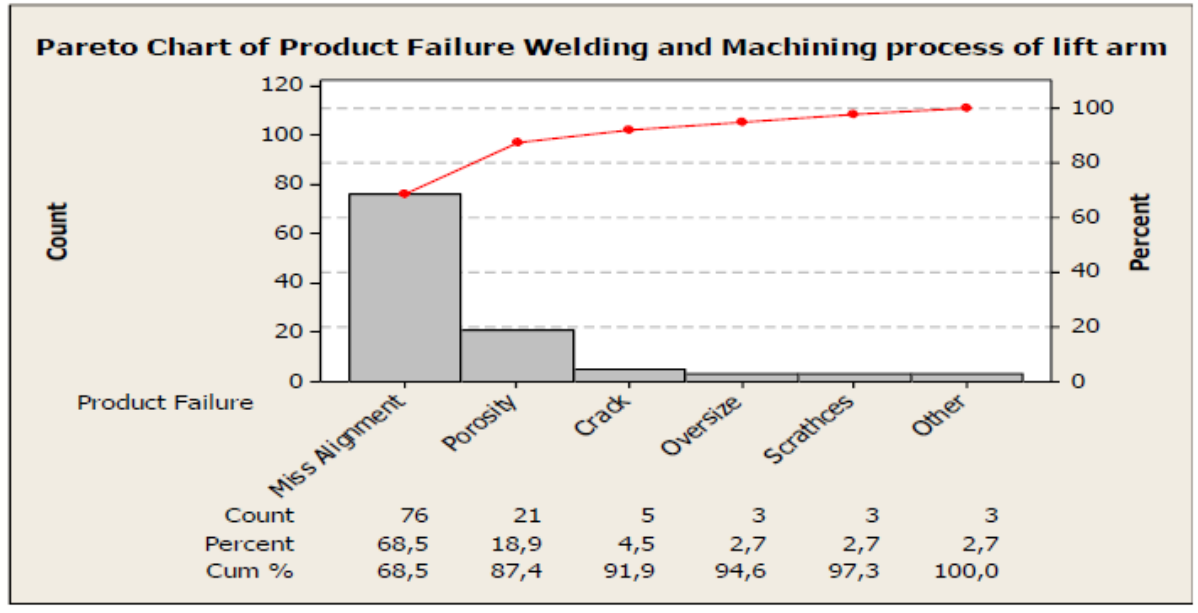

Figure 3. Pareto chart of product failure welding and machining process of lift arm.

\subsection{Measure phase}

The measuring stage is the second stage in the quality improvement program with the Six Sigma method in this stage, the capability process/sigma level measurement is used to determine the ability of the process before improvement, plotting the ability of the process into 4 block diagrams to determine the improvement direction from the control side of technology and also carried out measurements cost of poor quality (COPQ) to determine the financial losses caused by defective products.

Based on the collection of production data and product failure (defects) in the Remanufacturing Lift Arm process from January to May 2019 obtained from the report of the production department and Quality control, the calculation of the process capability/sigma level is shown in Table 1.

Table 1. Measurement of level sigma current condition that representative of before improvement

\begin{tabular}{cc}
\hline Item & Value \\
\hline Total Production & 266 \\
Total Product Failure (defect) & 111 \\
CTQ & 2 \\
DPMO & 834586,47 \\
Level of Sigma & 1,91 \\
\hline
\end{tabular}

Four block diagrams are a description of a process and states improvement direction that leads to two sides of improvement, namely technology and control which is a description of the ability of the process $(Z)$ of an ongoing process. Based on Sigma Level 1.91, it can be calculated Zshif value as a reflection of control ability and Zst value which reflects the ability of technology and then plots it in Four block diagrams that show the capability of the ongoing process $(Z)$. The Zshif and Zbench.lt calculations in the four-block diagram are as follows:

$$
\begin{array}{ll}
\text { Zst } & =\text { Zbench.lt }+1.5 \\
1.91 & =\text { Zbench.lt }+1.5 \\
\text { Z bench.lt } & =1.91-1.5 \\
& =0.41 \\
\text { Zshift= Zbench.st }- \text { Zbench.lt } & =1.91-0.41 \\
& =1.50
\end{array}
$$

The next step is after knowing the value of $\mathrm{Z}$ shif (control ability) and Zst (sigma level) then it can be done by making four block diagrams to illustrate the current process condition (current condition), as for the Four block diagrams referred to are as in Figure 4.

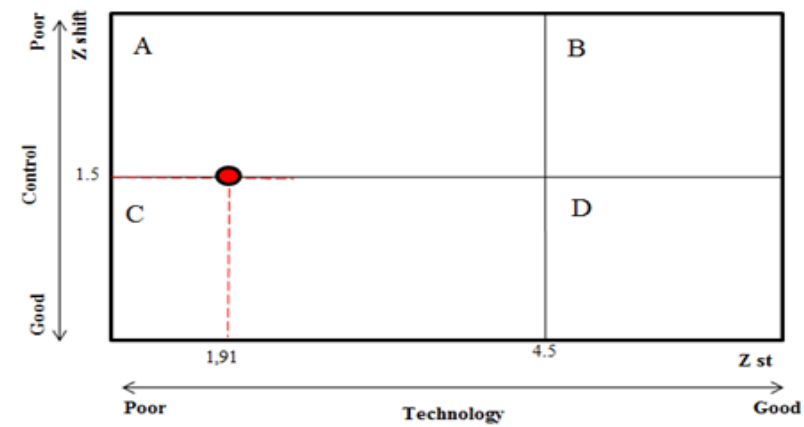

Figure 4. Four block diagram of product failure welding and machining process of lift arm

Looking at the Four block diagram above (Figure 4), it is known that from the control side it is good and still lacking in technology, meaning that improvements are needed so that both sides are expected in the category of proper control and technology. 
In addition to measuring the baseline performance of the Remanufacturing Lift Arm process, a cost analysis is also carried out due to poor quality, in this case, the cost of losses caused by product failure. The company's internal source costs must be borne due to product failure resulting in rework or rework. As a result, the costs of losses due to product failure in January - May 2019 are as follows:

Table 2. Calculation of cost of poor-quality January - May 2019

\begin{tabular}{cccc}
\hline No & Month & Product Failure (Pcs) & COPQ (IDR) \\
\hline 1 & January 2019 & 22 & $127,000,000.00$ \\
2 & February 2019 & 18 & $115,000,000.00$ \\
3 & March 2019 & 22 & $122,000,000.00$ \\
4 & April 2019 & 23 & $134,800,000.00$ \\
5 & May 2019 & 26 & $152,000,000.00$ \\
\hline & Total & 111 & $650,800,000.00$ \\
\hline
\end{tabular}

Table 2 shows the cost of losses resulting from product failure from January to May 2019 Cost of Poor Quality of IDR $650,800,000.00$.

\subsection{Analyze phase}

Analyze Phase is the third stage of the DMAIC method. In this stage, what needs to be done is to analyze why deviations or product failure occur by looking for the causes that cause these product failures. In this case, a defect analysis arises in the Remanufacturing Lift Arm process which consists of 2 types of product failure e.g. alignment and porosity Fishbone diagram (Cause and Effect diagram) as in Figures 5 and 6.

From the cause and effect diagram, in Figure 5 the root cause of Miss Alignment in the Remanufacturing Lift Arm process is: (1) The process cannot be done in a CNC machine because parts are longer than the machine table. (2) If done with a Portable Line boring machine, the machining and inspection process is done manually so that it depends on the operator's skill. (3) Different parts condition when received such as bending, crack, and welding results from the previous process are uneven. (4) There is no standard process using jigs and fixtures. (5) The absence of standard parameters, methods for the machining process. From the cause and effect diagram, in Figure 6. the root cause of Porosity in the Remanufacturing Lift Arm process is (1) Dirty, oil-contaminated, grease and inconsistent surface cleaning by grinding before welding. (2) The welding process is carried out without Jigs, fixtures, parameters, and procedures as well as the inconsistency of checking after welding. (3) Humid winds and conditions in the welding area. (4) Difficult welding for inner diameter. (5) Uneven Welder Skill.

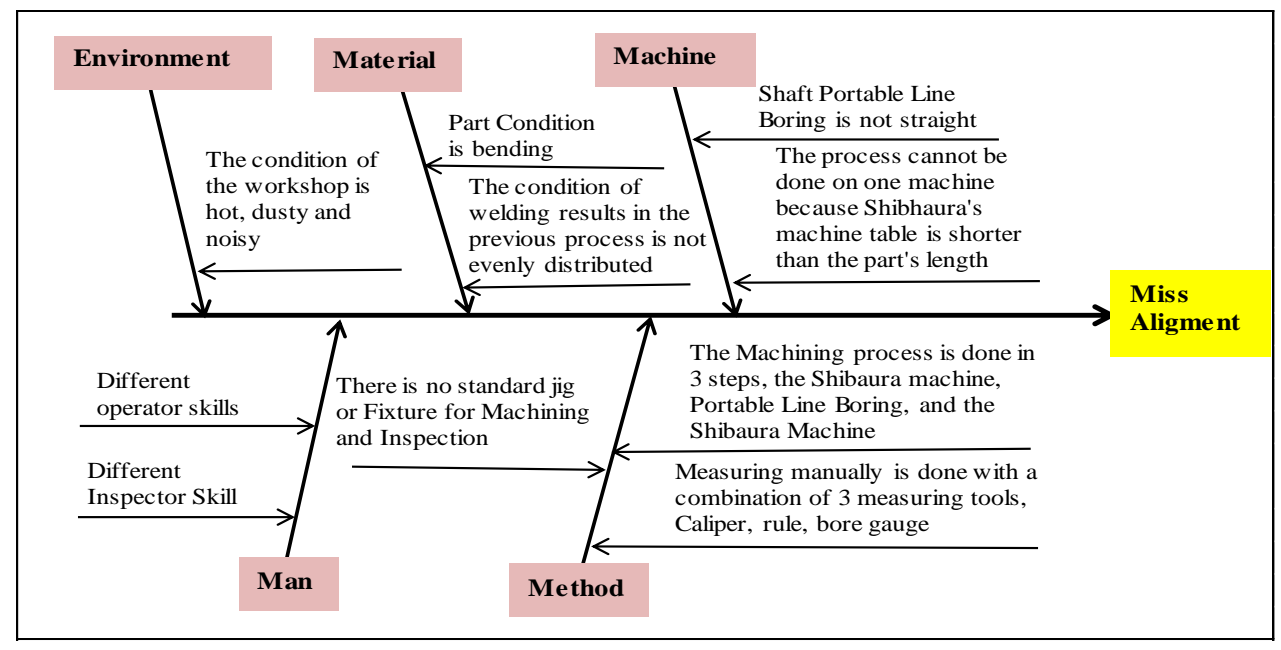

Figure 5. Cause and effect diagram of product failure miss alignment

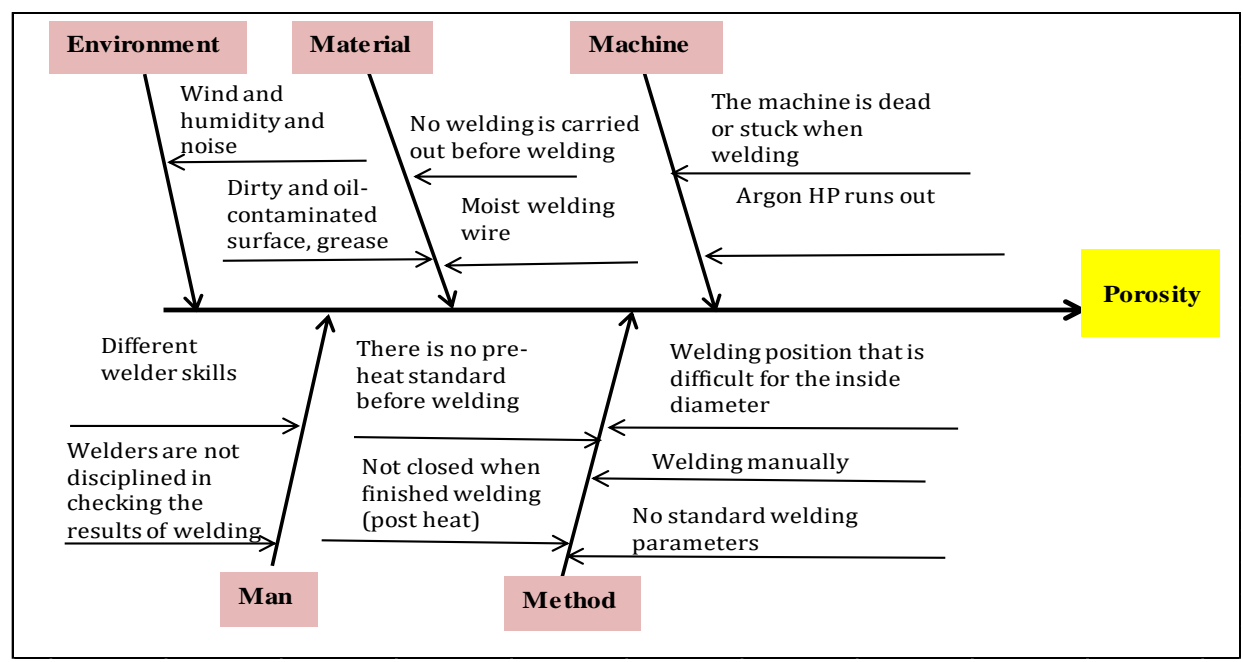

Figure 6. Cause and effect diagram of product failure porosity 


\subsection{Improve phase}

Improve stage is determining the proposed improvement of the root causes that have been done at the Analyze stage. The improvement plan is carried out using the $5 \mathrm{~W}+1 \mathrm{H}$ method that contains plans and corrective actions for each of the factors causing product failure Miss Alignment and porosity that have accumulated $80 \%$ of the largest product failures from the overall product failures that occur in the welding and machining process.

\subsubsection{Improve plan product failure miss alignment}

Miss Alignment product failure that occurs in the machining process is a major problem in the Machining process based on joint discussion with the $5 \mathrm{w}+1 \mathrm{H}$ method. Miss alignment problem is reconditioned: The Machining process changes from a manual process with 3 settings to 1 time setting with "Jig". This changes from the previous process of series per 12 holes into 10 holes directly in 5 different places. The inspection or checking process can also be reduced by eliminating the alignment checking/alignment from using the meter, caliper, ruler, thread and pendulum become unnecessary because the Jig hole size has been adjusted to the part specifications. Quality Control focuses on checking dimensions with bore gauge and caliper and visual smoothing of machining results. The process is faster than the previous 4 days to 2 days so that it can increase the capacity of workshops that were previously 13-14 units to 24-25 units per month. The engine parameters with a speed of $200 \mathrm{rpm}$, feeding rate. 1,2 and feeding $0.5-1 \mathrm{~mm}$ per step. From the operator side, this process will change from grade 4 or multi-skill CNC operator to grade 2 semi-automatics. The Jig referred to above is as in Figure 7.
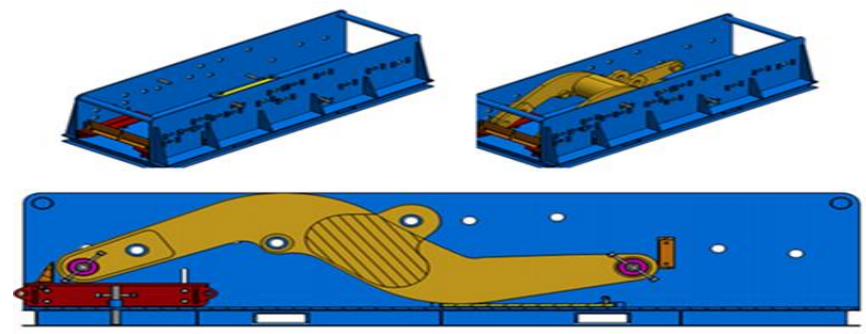

Figure 7. Jig machining process design to reduce miss alignment

\subsubsection{Improve plan product failure porosity}

Product Porosity failure that occurs in the Welding process is a major problem in the Machining process based on joint discussion with the $5 \mathrm{w}+1 \mathrm{H}$ method. Miss alignment problem is reconditioned: The welding process for Inside diameter or the inner hole is replaced from before the manual process becomes semi-automatic by modifying the machine and making Jigs and fixtures. With this process, a change occurred before Welder did welding to just run the machine correlated with Jigs and fixtures so that the welding results will be standard, even and the operator can prepare other parts in the queue. The making of Welding Procedure Standard starts from the cleaning process with chemical and grinding, preheat up to a temperature of $120^{\circ}$ Celsius, welding and PWHT with glass wool after finishing. In the surrounding area of welding made a cover or screen to keep the wind and humidity. The improvements to the welding process in question are shown in Figure 8.
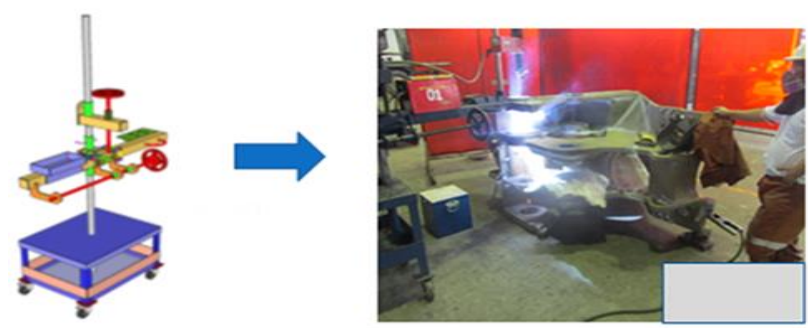

Figure 8. Jig welding process design to reduce porosity

\subsection{Control phase}

This stage is the final phase of the DMAIC phase. What is done at this stage is monitoring and controlling the results after improvement. Process capability/sigma level, mapping sigma level into four blocks are salted and the calculation of the cost of poor quality (COPQ) is again carried out to determine the effectiveness of the results of improvements, in addition to the process of standardization of new processes that are also carried out to avoid similar failure products occurring in the future.

Based on data taken from the production and quality control department with a duration from the first week of July 2019 to the fourth week of November 2019, the total production for Lift Arm is 341 units with a total of 24 units of product failure, with a percentage of $7.03 \%$. The calculation of process capability/sigma level is presented in Table 3.

Table 3. Measurement of level sigma current condition that representative of after improvement

\begin{tabular}{cc}
\hline Item & Value \\
\hline Total Production & 341 \\
Total Product Failure (defect) & 24 \\
CTQ & 2 \\
DPMO & 140762.5 \\
Level of Sigma & 2.43 \\
\hline
\end{tabular}

Table 3 Shows that the capability of the welding and machining process after Improvement is at 2.4 sigma with DPMO 140762.50 better than the conditions before Improvement 1.91 sigma with DPMO 834586.47.

Referring to Table 3 above the same calculation as in the mature stage, the sigma level after improvement (2.43) can be mapped in the four-block diagram as in Figure 9.

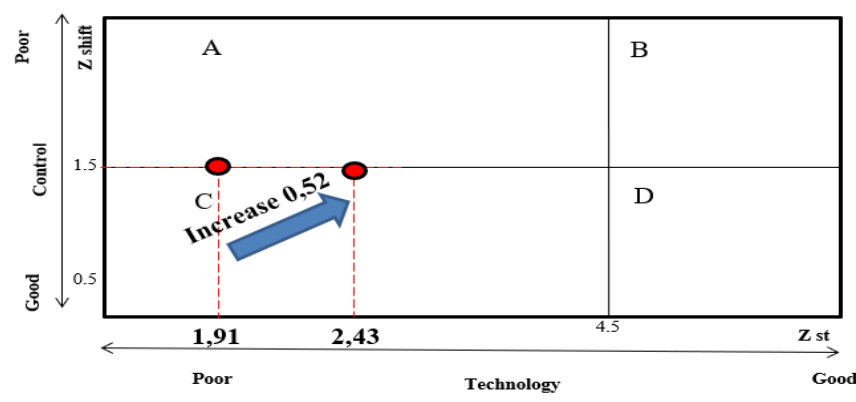

Figure 9. Four block diagram product failure welding and machining process lift arm (Before and after improvement)

Just as in the measuring stage, the calculation of the cost of poor quality (COPQ) is a calcula-tion of the company's losses that must be borne by the product failure that occurs. The COPQ calculations after improvement can be seen in Table 4. 
Table 4. Calculation of cost of poor quality July November 2019

\begin{tabular}{cccc}
\hline No & Month & $\begin{array}{c}\text { Product Failure } \\
\text { (Pcs) }\end{array}$ & COPQ (IDR) \\
\hline 1 & July 2019 & 5 & $28,000,000.00$ \\
2 & August 2019 & 5 & $28,000,000.00$ \\
3 & September & 5 & $28,000,000.00$ \\
4 & October 2019 & 5 & $28,000,000.00$ \\
5 & November & 4 & $23,000,000.00$ \\
\hline & 2019 & 24 & $135,000,000.00$ \\
\hline
\end{tabular}

Table 4 Above can be interpreted that the loss that must be borne by the company due to product failure after improvement as much as IDR 135,000,000.00 decreased from before im-provement IDR $680,800,000.00$ equivalent to $78.71 \%$.

Quality improvement from the production of 266 pcs with the number of defects 111 pcs to the production of 341 pcs with the number of defects 24 pcs, proving that the six sigma medology is very good for reducing the defect rate.

To avoid similar failure products, namely Miss Alignment and Porosity Lift Arm in the process of welding and machining in the Indonesian remanufacturing industry, socialization of the results of improvement to all relevant levels and the creation of new standards in the form of Opera-tional Procedure Standards (SOP) related to welding and machining processes.

\section{CONCLUSIONS}

Referring to the entire stages of this research, it can be concluded that improving quality by using the Six Sigma method in this study can reduce Lift Arm failure products in the welding and machining process and can increase company profits due to decreased product failure. This study generally strengthens previous studies that the Six Sigma method is effective in identifying and analyzing product failures, and can improve the capability/level of sigma to get better quality products. Seeing the positive results contained in this study, it is recommended for further studies the use of the Six Sigma method in combination with other tools of quality can be used in improving quality in the other remanufacturing industries. To increase the repertoire of research using the Six Sigma method becomes more varied.

\section{REFERENCES}

[1] Valles, A., Sanchez, J., Noriega, S., Nuñez, B.G. (2009). Implementation of Six Sigma in a manufacturing process: A case study. International Journal of Industrial Engineering: Theory, Applications and Practice, 16(3): 171-181.

[2] Gijo, E.V., Antony, J., Kumar, M., McAdam, R., Hernandez, J. (2014). An application of Six Sigma methodology for improving the first pass yield of a grinding process. Journal of Manufacturing Technology Management, 25(1): 125-135. https://doi.org/10.1108/JMTM-12-2011-0109

[3] Hassan, M.K. (2013). Applying lean six sigma for waste reduction in a manufacturing environment. American
Journal of Industrial Engineering, 1(2): 28-35. https://doi.org/10.12691/ajie-1-2-4

[4] Suwendra, W.I. (2014). Manajement Kualiats Total. Yogyakarta: Graha Ilmu.

[5] Juran, J.M., Godfrey, A.B., Hoogstoel, R.E., Schilling, E.G. (1998). Juran's Quality Handbook, Fifth Edition, New York, A Devision of McGraw-Hill Companies.

[6] Purba, H.H., dan Aisyah, S. (2017). Quality Improvement and Lean Six Sigma. Yogyakarta: Expert.

[7] Bauer, J.E., Duffy, G.L., Westcott, R.T. (2006). The Quality Improvement Handbook, Milwaukee, American Society for Quality: Quality press.

[8] Nugroho, D.M. (2015). Pengaruh kualitas pelayanan, kualitas produk layanan, dan harga produk layanan terhadap kepuasan pelanggan serta dampaknya terhadap loyalitas pelanggan prabayar telkomsel. Jurnal Operations Excellence, VII(2): 158-174.

[9] Parasuraman, A., Grewal, D. (2000). The impact of technology on the quality-value-loyalty chain: A research agenda. Academy of Marketing Science. Journal. Winter, 28(1): 168-174. https://doi.org/10.1177/0092070300281015

[10] Montgomery, D.C. (2009). Statistical Quality Control: A Modern Introduction. Sixth Edition. John Wiley \& Sons, Inc. Asia.

[11] Kheng, L.L., Mahamad, O., Ramayah, T., Mosahab, R. (2010). The impact of service quality on customer loyalty: a study of banks in Penang, Malaysia. International Journal of Marketing Studies, 2(2): 57. https://doi.org/10.5539/ijms.v2n2p57

[12] Jandaghi, G., Mehranjani, R.N., Seresht, M.N., Mokhles, A. (2011). Studying the effect of brand loyalty on customer service inkerman asia insurance company. Australian Journal of Business and Management Research, 1(6): 152-158.

[13] Rego, L.L., Morgan, N.A., Fornell, C. (2013). Reexamining the market share-customer satisfaction relationship. Journal of Marketing, 77(5): 1-20. https://doi.org/10.1509\%2Fjm.09.0363

[14] Ijomah, W.L. (2002). A model-based definition of the generic remanufacturing business process. University of Plymouth Research Theses.

[15] Ijomah, W.L. (2008). Addressing decision making for remanufacturing operations and design-forremanufacture. International Journal of Sustainable Engineering, 2(2): 91-102. https://doi.org/10.1080/19397030902953080

[16] Ijomah, W.L., Childe, S. (2010). A model of the operations concerned in remanufacture. International Journal of Production Research, 45(24). https://doi.org/10.1080/00207540601137181

[17] Amezquita, T., Hammond, R., Salazar, M., Bra, B. (1995). Characterizing the remanufacturability of engineering systems. Proceedings 1995 ASME Advances in Design Automation Conference, Boston. Massachusetts, 82: 271-278.

[18] Goetsch, D.L., Davis, S.M. (1994). Introduction to Total Quality: Quality, Productivity, Competitiveness (Merrill's international series in engineering technology). Englewood Cliffs, NJ, Prentice Hall International Inc.

[19] Ramana, R.S., Basavaraj, Y. (2018). Defect reduction in a capacitor manufacturing process through Six Sigma concept: A case study. Management Science Letters, 9: 253-260. 
[20] Adeyemi, Y., Needy, K.L. (2006). Analysis of Six Sigma at Small vs. Large Manufacturing Companies. Department of Industrial Engineering University of Pittsburgh Pittsburgh, PA 15261, USA.

[21] Gerger, A., Firuzan, A.R. (2016). Use of Six Sigma Method as a Process Improvement Technique: a Case Study in Aerospace Industry. Academic Journal of Science, 06(01): 191-202.

[22] Pande, P.S., Neuman, R.P., Cavanagh, R.R. (2000). The Six Sigma Way: How GE, Motorola, and Top Companies are Honing Their Performance. https://doi.org/10.1007/978-3-8349-9320-5_24

[23] Mittal, M. (2014). Latest Trend in Management - Six Sigma. Gian Jyoti E-Journal, 4(1): 32-38.
[24] Syafwiratama, O., Hamsal, M., Purba, H.H. (2017). Reducing the nonconforming products by using the Six Sigma method: A case study of a polyester short cut fiber manufacturing in Indonesia. Management Science Letters, 7(2017):

153-162. https://doi.org/10.5267/j.msl.2016.12.001

[25] Trimarjoko, A., Saroso, D., Purba, H., Hasibuan, S., Jaqin, C., Aisyah, S. (2019). Integration of nominal group technique, Shainin system and DMAIC methods to reduce defective products: A case study of tire manufacturing industry in Indonesia. Management Science Letters, 9(13): 2421-2432. https://doi.org/10.5267/j.msl.2019.7.013 